\title{
LOS PENITENCIALES: POSIBLE FUENTE DE LAS PRIMITIVAS COMEDIAS EN VULGAR
}

\author{
José Luis Canet Vallés \\ Universitat de València
}

Mucho se ha escrito sobre el amor, sexualidad y gula en los orígenes del teatro español. Algunas veces, se resalta el extremado erotismo, llegando a clasificar estas comedias de obscenas, y se justifica esta amoralidad a través de la relajación de costumbres imperante en la sociedad anterior al Concilio de Trento; otras veces, por el contrario, se insinúa una tímida "reprobación del amor," enlazando con la tradición medieval de los remedia amoris, o se habla de "parodias" de comportamientos corteses. Posiblemente se puedan aunar ambas posturas aparentemente contradictorias, como intentaremos demostrar a lo largo de este trabajo. El corpus escogido se centra en las primeras variaciones españolas de la comedia humanística, sobre todo en Celestina y sus imitaciones posteriores, así como en otras mal llamadas imitaciones celestinescas (Thebayda, Serafina, Ypólita).

De todos es bien conocido que desde la más remota antigüedad se asignaba la temática amorosa a la comedia. Así el gramático Diómedes asigna los ainores, que no el ainor, a la comedia,; Isidoro de Sevilla habla de los stupra virginum et amores meretricum como objeto propio de la

${ }^{1}$ Como dice el autor de la Serafina: "Pues sabe, sabe que ese apetito que mueve a la voluntad umana se llama amores y no amor," y el Diccionario de Autoridades: "En nuestra lengua se toma por los amores profanos y lascivos, que son los que tratan los enamorados." 
comedia. ${ }^{2}$ El amor, como simple sexualidad, acompañará desde siempre los géneros denominados 'menores,' como los fabliaux, las novelle italianas, la farsa europea, e incluso los exempla y cuentecillos populares, pero sobre todo será el tema central de la comedia.

La comedia elegiaca y humanística medieval se construyen a partir de los modelos del teatro romano y de los preceptos retóricos y poéticos, adquiriendo así temas (el amoroso), enredos y fórmulas compositivas de la tradición. La comedia cumplía, además, una función didáctica y moral dentro del ambiente en el que se inscribía, el universitario, tal y como proponian los gramáticos de la latinidad. Donato y Servio, por ejemplo, daban particular relieve a esta función didáctica. El estilo cómico adquirió un mayor relieve moral durante el periodo del humanismo al fundamentarse en Cicerón (Pro Sexto Roscio, $16,47)$, quien sugiere que el autor de comedias represente nuestras costumbres encarnadas en otras personas, poniéndonos con ello ante los ojos una imagen viva de nuestra vida cotidiana. La finalidad de estas imágenes es, según Servio, permitirnos reconocer en ellas nuestros propios defectos y corregirlos. ${ }^{3}$ Pero para no entrar en colisión con la sátira, siempre desde el punto de vista retórico, se muestran unos personajes a los que se les ha quitado la individualidad. Se describe a los "peores", que no son ni más ni menos que representaciones en carne y hueso de los vicios. El personaje se caricaturiza al desaparecer la concreción histórico-personal (la denuncia de hombres reales), pero sin perder por ello la finalidad de corrector de costumbres.

Estos vicios que aparecen de forma repetitiva son el elemento humorístico y ridículo pero al mismo tiempo reprobatorio de ciertos comportamientos sociales esclavizados por su sensualidad inferior (sexo y gula), de forma algo similar a como los denunciaban los autores moralistas de la época. Se entra así en una de las facetas más importantes de la comedia renacentista, el ridentem dicere verum horaciano junto al prodesse et delectare. De ahí que, como ha dicho Lida de Malkiel de la comedia humanística, "con pocas excepciones, el tema central es un amor ilícito, ya meretricio, ya adulterino, ya resuelto en casamiento; el argumento es siempre muy sencillo comparado con el de la comedia

2 "Comoedi sunt qui privatorum hominum acta dictis aut gestu cantabant, atque stupra virginum et amores meretricum in suis fabulis exprimebant" (Etimologiarum, XVIII, 46).

${ }^{3}$ Ver Margarete Newels, Los géneros dramáticos en las poéticas del Siglo de Oro, London: Tamesis, 1974, p. 76. 
romana [...] Prueba de la atención de la comedia humanística a lo contemporáneo es su tendencia a la sátira, no porque las obras hayan sido concebidas con intención moralizante, sino porque de pasada gustan de exponer flaquezas y vicios, siendo mujeres y clérigos el blanco predilecto."4 Estoy de acuerdo con la ilustre hispanista, excepto en lo de la sátira y moralización, que hemos comentado en parte y trataremos a lo largo de este estudio.

El amor en la literatura es asimilado a los vicios y pasiones a evitar; pero ¿qué tipo de amor? Se trata del amor erótico en sus diferentes facetas: bien el denominado hereos o ilisci según la tradición médica, donde se le describe como pasión desorbitada y enfermedad, ${ }^{5}$ bien los amores lujuriosos o concupiscentes, según la tradición eclesiástica. Es decir, literariamente había que mostrar pasiones desmesuradas (capaces de destruir al hombre, haciéndole perder su libre albedrio, razón y las potencias intelectivas, llegando incluso hasta la muerte física), o viciosos concupiscentes y lujuriosos bajo los aspectos más usuales de la vida cotidiana. La primera opción se reservó a lo que denominamos "ficción sentimental"; ${ }^{\circ}$ la segunda a la comedia como espejo de la vida, ya que ésta era la forma más común de "enamorarse" en las ciudades (sobre todo en aquéllas en las que existía una universidad con cientos de muchachos procedentes de lugares lejanos, sin padres que los vigilaran).? Por tanto,

${ }^{4}$ La originalidad artística de 'La Celestina' (Buenos Aires: EUDEBA, 1962; 1970²), p. 40 .

${ }^{5}$ Por ejemplo, hercos es el nombre dado al mal de amores por Constantino el Africano y la tradición médica procedonte de los griegos; ilisci como lo denomina Avicena y la tradición médica árabe.

6 Ver José Luis Canet, "El proceso del enamoramiento como elemento estructurante de la ficción sentimental," en Historias y ficciones: Coloquio solve la literatura española del siglo XV (Valencia, 29-31 de octulire de 1990) (Valencia: Universidad-Dept. de Filologia Espanyola, 1992) pp. 227-239.

${ }^{7}$ Ese parece ser el punto de vista de Teresa Ferrer cuando indica: "Si hay algo que une a los personajes más representativos del primer Renacimiento, es su camalidad. Pastores rústicos y pastores sofisticados, caballeros y escuderos, damas, criados y criadas (y, más secundariamente, frailes, ermitaños, rufianes (...), todos sufren con la misma fuerza los acontecimientos de la carne. Una esperaría encontrar debajo de tantas quejas por amor, llantos, suspiros y declaraciones de fe y servicio, llagas, heridas sangrantes, requiebros, enajenaciones, amenazas de muerte y suicidio, alguna huella, que no fuese sólo retórica, de las corrientes neoplatonizantes en boga en la Europa del Renacimiento. No es asi. En la 
al tener que poner en escena o retratar en la comedia a los "peores," a los más viciosos, los autores escogen a prototipos que transgreden cada una de las normativas en vigor, tanto cristianas como éticas.

Hagamos un breve repaso de la concepción amorosa imperante y defendida por el cristianismo para podemos hacer una idea del antihéroe amoroso del hombre culto medieval y renacentista. Creo que está asumido por todos que el cristianismo propuso una modificación de las costumbres amorosas de lo judíos y romanos. San Pablo aceptó el dictamen de Jesús sobre la indisolubilidad del matrimonio $y$, al igual que él, no sólo relegó sino que, en realidad, ignoró el mandamiento de procrear. Antes bien suele hablar del matrimonio en términos negativos, como un remedio para aquellos demasiado débiles. San Pablo admite que el matrimonio en sí no es pecado, sin embargo, afirma que convierte a los cónyuges en esclavos de las necesidades y deseos sexuales, no siendo libres para dedicar sus energías al "Señor" (I Corintios, 7, 29-35). El Apóstol ve la actividad sexual, e incluso el matrimonio, como una forma de esclavitud: " $\mathrm{O}$ no sabéis que quien se une a la prostituta se hace un cuerpo con ella? Pues está dicho los dos se harán una sola carne" [Génesis 2:24]; compara entonces la relación sexual con la unión espiritual del creyente en Cristo: "Mas el que se une al Señor se hace un solo espíritu con El" (I Corintios 6:17). Declarará, pues, que todos deberían ser célibes por propia voluntad, por amor al reino, como él mismo (I Corintios, 7, 7-9). Los solteros evitan las ansiedades y obligaciones que importunan a los casados; no sólo son más libres sino más felices. No obstante admite que "si no pueden contenerse, que se casen; mejor es casarse que abrasarse." Pero alienta, incluso a los casados, a vivir como si estuvieran solteros: "Los que tienen mujer vivan como si no la tuviesen" (I Corintios $7,29)$.

En el siglo IV hay una primera unificación de la filosofía cristiana. Se acepta el Génesis como relato verdadero de la creación del mundo y de él se extraen prácticas de comportamiento. Tertuliano explica así la inferioridad de la mujer, basándose en Génesis 3: "Vosotras sois la puerta del infierno... tú eres la que convenció a él a quien el diablo no se atrevió a atacar... ¿No sabéis que cada una de vosotras es una Eva? La sentencia de Dios sobre vuestro sexo persiste en esta época, la culpa, por necesidad, persiste también" (De cultu feminarum, I, 12).

gestación de la comedia la influencia de La Celestina fue decisiva, y caballeros y damas se vieron, como Calixto y Melibea, sometidos a los envites de la pasión (...)," en "El erotismo en el teatro del primer Renacimiento," en Edad de Oro 10 (1990): 51-62, en 51-52. 
También advierte contra la gula, porque "el comer hizo caer a Adán" (De jejuniis, 3) y confirma la monogamia, porque Dios hizo a Adán "sólo una mujer" (De exhortatione castitatis, 5). San Jerónimo, en su defensa de la virginidad y castidad, insistirá en que al principio Adán y Eva estaban destinados a ser vírgenes, y se unieron en matrimonio sólo tras haber pecado y como castigo fueron expulsados del "Paraíso de la virginidad" (Epistola 22, 18). ${ }^{8}$

Partiendo del Génesis, el dolor, sufrimiento y muerte eran vistos por los cristianos como el castigo natural al pecado cometido por nuestros primeros padres. Uno de los autores más importantes para la teoría sobre la naturaleza humana y la causa del pecado fue S. Agustín, quien rebatió los planteamientos de Pelagio y de Juliano, los cuales sugerían una naturaleza no contaminada por el pecado de Adán y creada por Dios. Para San Agustín, si la naturaleza es mala lo es a causa del pecado; el deseo sexual no puede proceder de la naturaleza pura inicial, no es ni más ni menos que obra del diablo, de ahí que surja en todos como una fuerza fuera de control (Contra Juliano, 2, 33). Incluso en el matrimonio encuentra "degradación sin límite de lujuria y ansia condenable" $(3,14)$. De no ser por las limitaciones impuestas por el matrimonio cristiano, "la gente se aparejaría sin discriminación, como los perros", comenta el Santo Padre, y añade: "¿Quién puede controlarse cuando despierta su apetito? ¡Nadie! .... En la tendencia de su apetito, no tiene modo de responder a la decisión de la voluntad" $(3,13)$.

El mismo presupuesto defenderá San Jerónimo en su famoso Adversus Jovininnum. Joviniano utilizaba para su defensa los textos deuteropaulinos, mientras que S. Jerónimo los que hoy denominados como auténticas epístolas; sus planteamientos sobre la sexualidad arrancan de I Corintios 7: "Si 'es bueno para un hombre no tocar a una mujer', es malo tocarla (...) [Pablo permite sólo el matrimonio] 'debido a la fornicación,' como si uno dijera 'es bueno comer la más delicada flor de trigo,' y sin embargo impedir que un hombre hambriento devore excrementos, yo también le permitiría comer cebada... la razón por la cual dice 'es mejor casarse' es que resulta peor quemarse (...) Es como si hubiese dicho "es mejor ser tuerto que completamente ciego, es mejor tener una sola pierna y apoyar el cuerpo en un bastón que arrastrarse sobre piernas rotas..." $(1,7)$. Se piensa, como lo había hecho Gregorio de

${ }^{8}$ Para estos aspectos sobre el primitivo cristianismo, ver Elaine Pagels, Adam, Eve, and the Serpent, Nueva York: Random House, 1988. Sigo la traducción española realizada por Teresa Camprodón, Adán, Eva y la scrpicnte, Barcelona: Crítica, 1990. 
Nisa, que la virginidad es el estado ideal del cristiano a imitación de Cristo, quien mediante el dominio de la sensualidad llegó a ser libre y alcanzar la resurrección.

El cristianismo, al tratar del amor, se centró ante todo en los peligros que ocasionaba, como lo habían realizado los estoicos y otros sabios de la antiguedad pagana. Es en lo que insiste S. Jerónimo: "Aristóteles y Plutarco y nuestro Séneca han escrito libros sobre el matrimonio, de los que extraemos muchas de las cosas que exponemos aquí. El amor por lo bello es un pérdida de la razón, casi la locura: vicio horrible muy poco conveniente a un espíritu sano.... El hombre sabio debe amar a su mujer con el juicio, no con la pasión. Que domine el arrebato de la voluptad y no se deje llevar con precipitación hacia la unión sexual. Nada es más infame que amar a su esposa como una amante. Con certeza, aquellos que dicen unirse a sus esposas en interés de la cosa pública y del género humano y para criar a los hijos, que imiten al menos a los animales $\mathrm{y}$, cuando el vientre de las esposas estará hinchado, que no corrompan a los hijos. Que no se presenten a sus esposas como amantes, sino como maridos..." (Adversus Jovinianum, en Patrologia Latina, XXIII, 280 y 281). Y todos los canonistas y manuales de confesores insisten en estos aspectos negativos de la actividad sexual, pero sobre todo en contra de la pasión amorosa, que esclaviza al hombre, haciéndolo de señor siervo.

Con Boecio y su Consolación de la filosofía se implanta un nuevo espíritu religioso que incorpora diversas proposiciones estoicas, ya expresadas por Cicerón y Séneca, a las de los Apóstoles y Santos Padres. Boecio sienta las bases filosóficas al demostrar que el Sumo Bien es únicamente Dios, mientras que la lujuria hace esclavo al hombre de sus propios deseos al perder su libre albedrío. En su prosa séptima, Libro III, muestra los errores en los que caen los hombres al creer que el placer de los sentidos puede dar la felicidad, puesto que entonces los brutos animales serían considerados los mas felices, ya que sólo aspiran a la satisfacción de sus deseos. En la prosa octava, Libro III, explica la esclavitud del hombe por su propio cuerpo, convirtiéndose en un simple animal irracional (aspecto que se vuelve a repetir en la prosa tercera, Libro IV: "Luego aquel que se ha dejado transformar por el mal o por el vicio no puede ser considerado hombre"). Por último, en su Quinto Libro cita al libre albedrío y a la razón como potencias esenciales del hombre, distinguiéndolo de las demás criaturas; y se "llegará al extremo de la esclavitud cuando, entregados a los vicios, pierdan la propiedad de la razón, que es su sello característico." Todos estos aspectos son los que aparecen explicitados en las comedias humanísticas, ya que los jóvenes 
galanes pierden su razón y libre albedrío al dar rienda suelta a sus pasiones amorosas, enlazando así con la filosofía moral.

En los penitenciales, el comportamiento amoroso y sexual viene descrito normalmente bajo los epígrafes de: "uniones ilícitas," "lujuria," "fornicación" o "fornicación y adulterio," etc. Estas relaciones amorosas se refieren tanto a los casados como a los solteros. Por ejemplo, S. Jerónimo calificaba como adúlteros a los esposos que "aman demasiado ardientemente a sus mujeres," citando al moralista pagano Sextus: "Unde Sextus in sententiis: Adulter es, inquit, in suam uxorem amator ardentior. In aliena quippe uxore omnis amor turpis est, in sua nimius" (En relación a la esposa de otro todo amor es vergonzoso; en relación a la suya, el amor excesivo). ${ }^{9}$ Aquí S. Jerónimo sigue la filosofía de los estoicos. Se acepta la actividad sexual siempre y cuando sea beneficiosa a la sociedad, pero hay que regular dicha pasión mediante reglas precisas. Los cristianos definieron "obra conyugal" al comercio sexual que observaba estas reglas, y "fomicación" y "adulterio" todo aquello que las trasgredía. A la "obra conyugal" se le atribuye la intención procreativa; a la fornicación y adulterio el amor, la pasión, la búsqueda del placer. ${ }^{10}$

Argumentando contra el concubinato, santo Tomás escribía: "Aquél que usa de la cópula para el placer que va junto al acto, no haciendo referencia a la intención de procrear, actúa contra natura" (Comentario sobre las sentencias, 4.33.1.3). En su libro De malo, 15, 2, obj. 14, indica que todo acto lujurioso es pecado mortal porque no conlleva a la generación y a la educación de la prole. Para el autor de la Sumina, el acto de lujuria no es injurioso al niño en potencia no creado al derrochar el semen, sino a la especie humana en general, cuya conservación se ve amenazada: "La emisión desordenada del semen es contraria al bien de la naturaleza, que es la conservación de la especie" (De malo, 3, 122). De ahí se pasa a que toda relación extraconyugal, sea biológicamente fértil o estéril, es un desorden en la emisión del semen, una injuria hecha a la especie humana, y por consiguiente a la Naturaleza y a Dios. Por el mero

${ }^{9}$ Contra Joviniano, 1, 49, en Patrolngía Latima, XXIII, 280-281.

${ }^{10}$ Ver Jean-Louis Fladrin, Un temps pour embrasser. Aux arighines de la morale. sexuelle occidentale (VI-XI siècle), París: Seuil, 1983. 
hecho que la relación sexual se busque fuera del matrimonio, tiene el placer como fin y por tanto pervierte el orden de la naturaleza. ${ }^{11}$

Pero ¿cuál es ese amor tan desmesurado que denuncian todos los teólogos y predicadores? Santo Tomás, San Buenaventura, Gerson, San Bernardo, etc., piensan que es aquél que hace olvidar al hombre el verdadero amor el de Dios. Por tanto se están reflriendo a la pasión amorosa en general, y no como se podría suponer a la depravación sexual. Incluso podríamos decir que puede ser definido como aquel pecado mortal que se comete al preferir el fin temporal y el placer terrenal a la felicidad en mayúsculas mediante la unión eterna con Dios. Es el amor-pasión que empezaba a asimilarse en la literatura con la cortesía.

Todos estos textos de los Santos Padres y teólogos se reproducen y se comentan durante los siglos XII, XIII y XIV, siendo San Agustín, San Jerónimo, Santo Tomás y Boecio los autores más comentados e imitados por los humanistas italianos y los preferidos por los españoles de fines del Cuatrocientos y principios del Quinientos. También se manejaron profusamente las Sentencias de Pedro Lombardo y los Comentarios a las Sentencias de Santo Tomás, puesto que eran textos de obligada enseñanza universitaria junto con las reglas canónicas. Pero sobre todo serán los penitenciales los textos básicos para marcar la normativa de comportamiento del buen cristiano; textos que irán modificándose progresivamente en los manuales de confesores, las decretales y sínodos obispales.

Esta preocupación por las normas morales de comportamiento del buen cristiano aparece por ejemplo, en el Libro Sinodal de 1410, realizado por el obispo Fr. Gonzalo de Alba, cuando el propio religioso comenta que: "queriendo e amando la salud de las animas de los clerigos, e por les mostrar carrera que rijan bien a sy e a los pueblos que les son encomendados, mandamos fazer una hordenança para ellos, porque sepan dar los sacramentos a sus subditos, e governar sus pueblos e a sy

${ }^{11}$ Pero este gasto o derroche del semen puede darse también en el interior del matrimonio, y todos los teólogos insisten sobre este hecho. Unos consideran pecado mortal la búsqueda del placer en las relaciones matrimoniales (San Raymundo, Summa, 4.2.8; San Bernardo de Siena, Sermones seráficos, 19.3). Otros ven un pecado venial (Santo Tomás, San Buenaventura, Jean Gerson, etc.). Todos, sin embargo, remiten o citan a San Jerónimo, para quien el amor demasiado apasionado con su mujer los convierte en adúlteros. Citas que se mantendrán en el siglo XVI, insistiendo que el amor con la mujer debe scr contenido, si no convierten a su propia esposa en prostituta. 
en la manera que deven de derecho (...)." Libro del que se hizo una copia para cada iglesia a costa de la fabrica. Este libro sinodal utiliza como fuente las Sentencias de Pedro Lombardo, los Comentarios a las Sentencias y la Summa theologica de Santo Tomás, la Sumına de S. Raimundo de Peñafort, la Summa auren de Enrique de Segusio y el Libro de las confesiones de Martín Pérez. ${ }^{12}$

Comentaremos inicialmente la parte del libro que corresponde al sexto mandamiento, tema central de las comedias: "Açerca del pecado de la luxuria preguntale si cometio forniçio sinple, la qual es quando seglar soltero conosçe soltera que nin es virgen (p. 216) nin religiosa. Si cometio estrupro, que es deflorar virgen i cometio adulterio, que es conosçer casada o ser conosçida de casado. Item, si cometio inçesto, que es dormir con parienta afine, carnal o espiritual, la qual se estiende a las afijadas e a las religiosas, maguer que conosçer religiosa o religioso es sacrilegio, por quanto se ofreçieron a Dios por voto de continençia, e eso mesmo entendemos de los clerigos de ordenes sacras. Item, demandele si cometio este pecado en lugar sagrado o non sagrado; item, en dias de festa o en tienpo de ayuno, o si cometio con una o con muchas, o si una vegada o muchas. Preguntele, otrosi, de las çircustanças que pueden agraviar este pecado (...). Otrosi, preguntele si fablo con mugeres a fin de pecar con ellas, o si alguna conçito a pecado, o si fue a la eglesia o a las pedricaçiones por ver las mugeres o el paresçer dellas. Item, si comio letuarios o espeçias calientes o otras cosas semejantes, por que podiese mas pecar."

Lo primero que resalta es que la mayoria de las comedias humanísticas y las primitivas representables ponen en acción un pecado de estupro, al presentarnos una relación amorosa ilegal (fuera del matrimonio) con una doncella joven y virgen (Melibea, Cantaflua, Florinda, etc.). Estupro que era considerado en los penitenciales como uno de los pecados más graves, siendo necesario para su absolución la confesión ante el obispo. Las penas iban desde los diez años de ayuno o excomunión durante quince años hasta la prohibición de casarse o tener actividades sexuales (si ya estaba casado) de por vida. La otra variación de la comedia, sobre todo la comedia latina o la humanística en latín (y de la Comedia Serafina en vulgar y otras muchas italianas), presenta un

${ }^{12}$ Ver Synodicum Hispanum, dir. de Antonio García y García, vol. IV: Ciudad Rodrigo, Salamanca y Zamora, Madrid: BAC, 1987; y del mismo autor, "La canonística ibérica medieval posterior al Decreto de Graciano," en Repertorio de Historia de las Ciencias Eclesiásticas en España, Salamanca, 1976, vol. V:382 y ss. 
caso de adulterio, pecado menor comparado con el estupro, pero con penas que oscilaban entre 3 y 5 años de ayuno y penitencia.

Se resalta en estas comedias la contravención a las normas cristianas realizadas por aquellos enamorados cuya única satisfacción es la del goce carnal, llegando muchas veces a caer en la herejia, al confundir el Sumo Bien o la felicidad con la posesión física de la amada, cayendo así en la idolatría y por tanto contraviniendo el primer Mandamiento de la ley divina, como dirá el Libro Sinodal: "Otrosi, preguntele si cayo en pecado de eregia, dudando en las cosas de la fe o sentiendo mal o aviendo opinion mala en ella, o contra los sacramentos de la Eglesia, (...). Item, si cometio ydolatria. Ca estas cosas son contra el primero mandamiento de la Ley." Además, estos jóvenes galanes, no se contentan, como harán la mayoría de sus criados, en cometer el "forniçio sinple," que es cuando "seglar soltero conosçe soltera que nin es virgen ni religiosa," para satisfacer sus necesidades sexuales; el galán necesita conquistar lo inexpugnable, lo dificultoso, lo inalcanzable por la mayoría de los mortales, de ahí su mayor caída.

Pero el obispo Gonzalo de Alba añade que en la confesión se debe preguntar, además, las circunstancias del pecado: "Devedes a saber que non tan solamente los pecados son de confesar quanto a la sustançia dellos, mas aun quanto a las çircustanças, e mayormente aquellas que agravian el pecado. E puesto que en todos los pecados ayan çiertas çircustanças, asi commo en el furto furtar del lugar sagrado o non sagrado, o en la gula comer mucho o comer golosamente, e asi de otras, enpero por quanto en el pecado de la luxuria son mas, por tanto açerca del deve guardar el confesor las çircustanças, las quales se contienen en este verso: 'Quis, quid, ubi, per quos, quotiens, cur, quomodo, quando: Quilibet obseruet, anime medicamina dando.'

Quis, convien a saber si el pecador es mançebo o viejo, onbre o muger, noble o villano, libre o siervo, persona sinple o puesta en dignidat o en ofiçio, sano o enfermo, sabidor o sinple, soltero o casado, seglar o caustral, clerigo o lego, ca, segund dize sant Agostin, 'tanto mal faz en el clerigo el mal pensamiento, commo en el lego la obra.' Item, si es pariente o estranno; item, christiano o judio o pagano o erege, o otras cosas semejables.

Quid: Si cometio adulterio o fornicaçion o homeçidio o otro pecado. Item, si el pecado que cometio, si es publico o ascondido, ca mas peca el que peca publicamente que el que es ascondido, ca el que peca publicamente, con su mal enxienplo muchos escandalisa e corronpe. (p. 222) 
Iten, si el pecado es muy grave, o pequenno o medianero. Item, si es viejo o nuevo.

Vbi: Si cometio pecado en lugar sagrado o fuera. Item, si en casa del sennor a que avia ser leal o fuera.

Per quos: Si puso medianeros o alcayuetes, ca todos los tales son culpados en el pecado, e el es atenudo por los pecados de todos ellos. Item, per quos convien a saber, por quales, o con quales o contra quales; si levo algunos mançebos a pecar a la puteria, o si pago por ellos, o a otros pecados, ca le deviera de abastar los sus pecados propios.

Quotiens: Deve el pecador, si lo sabe, dezir quantas vezes cayo en el pecado, e el confesor de preguntar gelo, e non tan solamente del numero de los pecados, mas aun de las vezes en que cayo en un pecado, e del numero de las personas con que peco, quantas palabras le dixo, e quantas vegadas, de denuesto o enjurias o blasfemias, ca, segund dize sant Agostin, la llaga doblada peor es de sanar.

Cur: Convien a saber que entençion lo movio; si fue tentado o si procuro el la tentaçion, asi commo muchos malos fazen, los quales toman bocados o espeçias o beven vino fuerte para conçitar la tentaçion, o faziendo violençia en su cuerpo por que sean mas fuertes en la obra del pecado; item, si peco de su grado o costringido, e el costrinimiento si fue con condiçion o asulutamente; item, si por pobreza, o en juego o con entençion de enpeçer.

Quomodo: En que manera peco, faziendo o padeçiendo, lo qual mejor se sabe por obra que por palabra.

Quando: $\mathrm{Si}$ en tienpo santo, asi commo en las festas e en las Quaresmas e en los dias de ayuno, o en otros dias. Item, si ante que cunpliese la penitençia o despues, ca mayor pecado seria ante que despues.

Sean avisados los confesores que destos pecados amonesten a sus pueblos que se guarden asi commo de la muerte e mas, ca la muerte mata el cuerpo, e estos pecados matan la anima e el cuerpo."

Podríamos decir, que la comedia primitiva nos presenta a unos amadores que transgreden casi todos los preceptos y cánones religiosos, continuando así la sátira y corrección de costumbres que había iniciado la comedia elegiaca y humanística. El enamorado no sólo suele cometer el estupro o el adulterio, sino que además lo realiza con todos los agravantes de los penitenciales: a) son cultos y han tenido una educación esmerada (Calisto, Berinto, etc.), con lo que no pueden argumentar desconocimiento de causa, como los simples del primitivo teatro, cuyo comportamiento está justificado por su escasa razón, moviéndose tan sólo por los sentidos corporales, como los brutos animales; b) el pecado cometido suele ser público, delante de sus criados, amigos, damas de compañía, etc.; c) en muchas de las comedias, dicho pecado se realiza en 
la iglesia, o ermita (caso de la Comedia Thebayda), es decir dentro de un lugar sagrado (posiblemente en la primitiva Celestina el primer encuentro entre los enamorados se dé en la iglesia); ${ }^{13}$ d) para la consecución de la amada todos los enamorados utilizan medianeros o alcahuetas, "ca todos los tales son culpados en el pecado, e él es atenudo por los pecados de todos ellos"; e) una vez conseguida a la amada, se insite en la repetición del mismo pecado, "ca, segund dize sant Agostin, la llaga doblada peor es de sanar," y lo mismo ocurre con las damas, las cuales una vez han probado el placer difícilmente se pueden apartar de él.

Se pinta al perfecto antihéroe, al peor de los "peores," a aquél que contraviene todas las normas conscientemente, aquél que rompe con los preceptos establecidos bajo una aparente impunidad. Al peor de todos no, porque en España desaparece prácticamente la tradición medieval de la comedia humanística y de muchas narrativas breves de poner en escena el peor de todos los pecados sexuales, el sodomítico o pecado nefando (caso del Janus sacerdos, De Cavichiolo, De Falso Hypocrita ...), pecado no mencionado ya en el Libro sinodal de 1410 y en la mayoría de los penitenciales posteriores. Sin embargo, se mantiene la tradición de la utilización de hechiceras, conjuros, etc., caso de la propia Celestina y parte de sus imitaciones, ${ }^{14}$ pecado igualmente grave y duramente castigado en los penitenciales, incluso con la excomunión de por vida.

Se me podría argüir que algunas de las comedias primitivas terminan en matrimonio, bien sea secreto o público, y por tanto la ejemplaridad negativa sería cuestionable. Efectivamente, muchas comedias finalizan en matrimonio, pero no por ello los personajes están exentos de culpa. Para los moralistas, y anteriormente para los Santos Padres, la intemperancia sexual, o lo que es lo mismo la lujuria, constituye no sólo un pecado, sino un vicio desde el punto de vista de

${ }^{\mathbf{2}}$ Martín de Riquer en su artículo "Fernando de Rojas y el primer acto de $\mathrm{La}$ Celestina," en Revista de Filología Española 41 (1957): 378-388, cree que este primer acto no transcurre en el huerto de Melibea, sino en una Iglesia, con lo que coincidiría con el planteamiento de la Thebayda de que los enamorados, además de volverse como "brutos arnadores" o como los rufianes o alcahuetas, utilizan los lugares sagrados para sus entrevistas amorosas. Un nuevo elemento más de estas reprobatio amoris, como confirmación de la herejía amorosa.

${ }^{14}$ Incluso en la comedia urbana de la primera mitad del XVI, como en el Auto de Clarindo. 
la naturaleza, puesto que el deseo de procrear se ve contrariado. ${ }^{15}$ Es decir, el acto sexual en sí es visto como algo negativo si no se tiene en mente la finalidad procreativa, y ésta sólo se puede dar desde el sacramento del matrimonio. El amor-pasión que define a los enamorados de la comedia jamás tiene presente el fin último del acto sexual, caracterizándose dicho amor por una pasión excesiva fuera de razón, condenada, como hemos visto supra, por todos los teólogos del cristianismo. Podríamos resumir la postura de la Iglesia a través de $S$. Jerónimo, quien insiste en que el amor, definido como pasión, siempre corresponde a la "fornicación" o al "adulterio," aun cuando sea entre amantes casados sacramentalmente, puesto que conlleva la búsqueda del placer y no de la procreación.

También "la palabra comoedia fue puesta en relación ya por Diomedes (siglo IV), etimológicamente, con el vocablo comedere. $Y$ así surgen definiciones como las siguientes: "carmina quæ in conuiuiis canuntur"; "carmen aptum comestioni" ... y apenas si falta en una pieza teatral de carácter pastoril."16 Es el otro vicio o pecado extensamente narrado en la comedia humanística latina, así como en las églogas pastoriles y el primitivo teatro religioso. De este vicio se nutre, por ejemplo, toda la Egloga reqresentada la mesina noche de Antruejo o Carnestollendas de Juan del Encina.

La gula estaba estrecharnente relacionada con la lujuria, de ahí que siempre se interrelacionaran y aparecieran conjuntamente en las comedias, sobre todo en los personajes de condición social más baja. S. Agustín lo explica asi: "Porque el primer Adán, establecido en el paraíso, perdió la gloria de la inmortalidad por la intemperancia de la gula (Génesis, III, 17); por ello Cristo, segundo Adán, restauró esa misma inmortalidad por la abstinencia. $Y$ porque habia caído en un pecado mortal, aquel que, contra el mandamiento divino, había probado del árbol prohibido, por ello, ahora, el que ayuna según el mandamiento del Señor merece, en toda justicia, la vida. El Salvador, en efecto, ha llevado a cabo esto para que por la misma vía por la cual las faltas fueron introducidas, sean purgadas: el hombre, porque pecó comiendo, debe corregirse con la abstinencia (...) Adán, en efecto, no conoció a Eva mas que después de la aparición de su intemperancia. Mientras en ellos duró

${ }^{15}$ Ver San Alberto Magno, Super Ethica, lib. III, lectio XIII, y Santo Tomás en su De malo, 15, 2.

${ }^{16}$ Ver Rainer Hess, El drama religioso románico como comedia religiosa y profana (Siglos XV y XVI), Madrid: Gredos, 1976, p. 54 y nota. 
la sobriedad, la virginidad en ellos quedó intacta; mientras se abstuvieron de la comida prohibida, se abstuvieron de los pecados contra el pudor. El hambre es amiga de la virginidad y enemiga del libertinaje; la saciedad, por el contrario, disipa la castidad y alimenta la atracción sexual." Posteriormente, S. Agustín comenta el ayuno de Cristo en el desierto: "El Señor realizó esto como un segundo Adán: lo que el primer hombre había perdido comiendo, él lo recobra ayunando, y conserva en el desierto la ley de la abstinencia dada en el paraíso (...) Adán, expulsado del paraíso, sufrió en el desierto inculto del mundo. En el desierto, pues, fue primeramente rechazada la salud del hombre, allí donde falta el alimento, donde faltan las delicias y donde falta también la mujer, causa de todos los males. (...) El desierto es pues conveniente a la salud, donde no hay Eva que persuada, donde no hay mujer que engatuse. Mirad qué cosa más admirable: en el paraíso, el diablo lucha con Adán y en el desierto lucha con Cristo; en todos sitios levanta trampas y engaños al hombre... pero allí donde encuentra una mujer, sale vencedor; donde no encuentra mujer, se retira vencido" (S. Agustín, Sermón CXLVII, in Quadragesima Vlll en Migne, PL., XXXIX, 2031).

En el siglo V, Isidoro de Sevilla se basa en el ayuno como remedio para los incontinentes: "Cristo (...) a dicho por su Apóstol: 'Es bueno no comer carne y no beber vino."' $Y$ también: 'Quien sea débil, que coma legumbres' (Romanos XIV). No es porque la carne sea mala y prohibida por eso, sino porque los alimentos carnosos engendran la lujuria de la carne: son en efecto calientes y alimentan todos los vicios (...) El pescado podemos comerlo porque el Señor lo admitió después de la resurrección (Juan XXI)" (S. Isidoro, De Ecclesinsticis Officiis, lib. II, cap. XLV en Migne, P.L., LXXXIII, 778).

En el Libro sinodal, se dice: "27. Del pecado de la gula: Açerca de la gula demandaras si codiçio comer desordenadamente. Item, si fue enbriago algunas vezes o si acostunbro de enbriagarse, ca entuençe seria mas grave pecado. Item; si comio o bevio sin neçesidat, fasta que non podiese mas. Item, preguntele si quebranto los ayunos de la Eglesia sin neçesidat, o los ayunos acostunbrados o los ayunos que le fueron dados en penitençia, con golosina. Item, si reçebio el Cuerpo de Dios non estando ayuno, o los otros sacramentos de la Eglesia, siendo sano e rezio e non estando en peligro ninguno; si en los dias de ayuno comio ante de la nona, e si en los domingos o en las festas comio ante que oyese misa, podiendola oyr. Si conbido alguno o tomo espeçias o letuarios, non por razon de melezina, mas por bever mas o por que el vino le sopiese mejor. Item, si fizo costa con conbido a los ricos e non a los pobres. Item, si trabajo por comer viandas delicadas o bien aparejadas." 
Esta será la actitud de la mayoría de los criados de la primitiva comedia, pero sobre todo de los más marginales: rufianes, prostitutas, alcahuetas, etc., cuya máxima aspiración es comer y beber sin moderación, llegando en muchas de las comedias a tener más importancia este pecado que el amoroso, o creándose escenas casi independientes de la acción principal con este motivo. También será el pecado o vicio más mostrado en el teatro religioso primitivo, pasando posteriormente a configurar personajes de la tradición pastoril, siendo los rústicos, pastores y bobos los encargados de mostrarnos esta forma de comicidad.

Por tanto, las primitivas comedias, al anunciarnos en los prólogos su intención moralizante como correctoras de costumbres, cumplen su finalidad al ponernos en escena unos personajes prototípicos de diferentes pecados capitales, verdaderos antihéroes de la moral imperante, como espejo de la vida. Los humanistas, defensores de la concepción estoica de que el bien supremo del hombre consistía en la sola virtud y para que se diera la virtud era preciso erradicar completamente todas las pasiones, utilizaron la comedia para mostranos a unos personajes dominados por las pasiones de los sentidos como modelos negativos. Es en el interior de este círculo culto y universitario, al cual se incorporará posteriormente la gran nobleza europea, donde adquiere verdadero sentido esta concepción ridícula o casi satírica del amor sexual y de la gula desordenada. Es en este universo (preocupado por la transcendencia y por dar sentido al cristianismo mediante sus tratados sobre la felicidad o el bien supremo, con continuas disertaciones acerca de las virtudes, poder de la fortuna, etc.), ${ }^{17}$ donde toma cuerpo y se desarrolla un amor completamente sexualizado, como antimodelo del hombre que aspira al dominio de sí mismo, presentándonos a aquéllos que se dejan atrapar en la más vieja telaraña de la humanidad, la de Cupido.

Lo hasta aquí expuesto no implica que estos dos vicios sean los únicos que aparezcan descritos en la comedia primitiva; los otros también fueron mostrados y configurados en personajes prototípicos (rufianes y algunos rústicos mediante la soberbia; mercaderes y criados por la avaricia; etc.). Sin embargo, el tema central de la comedia continuó siendo el de los amores pecaminosos entre jóvenes incontinentes y la gula entre la gente baja, como definían las preceptivas imperantes en el momento.

${ }^{17}$ Paul Oskar Kristeller, El pensamicnto renacentista y las artes, Madrid: Taurus, 1986, p. 31. [Título original: Renaissance Thought II, Princeton: Princeton UP, 1965.] 
Los humanistas, en su afán de imitar la vida, escogen personajes jóvenes y cultos (en los que la pasión está más enraizada -como decía Aristóteles en su Retórica), como antihéroes. Pero para la configuración caricaturesca bien pudieron basarse en los penitenciales, los decretales y libros sinodales, como el que hemos expuesto aquí, acumulando así en uno o varios tipos sociales todos los pecados (sobre todo los referidos a la sexualidad), mostrándonos a los "peores", a los que no debemos imitar.

En épocas algo posteriores, hacia mitad de siglo, como sagazmente ha intuido Teresa Ferrer, la postura de la Iglesia cambió e "incluso aunque se corrijan los defectos en que habían incurrido los personajes de La Celestina (así en la Comedia Vidriana de Jaime de Huete), lo que debía quedar en el público o en el lector asiduo de piezas teatrales era más el cuadro de costumbres que la finalidad moral. En este sentido es significativa la postura de Vives que se debate entre la aprobación de La Celestina, dando el castigo final de los amantes (en su De ratione dicendi), y su condena (en su Institutio feminæ christianx)(...)."18 Aspecto que ya se podía vislumbrar en el Libro sinodal de 1410, cuando el obispo Gonzalo de Alba sugiere: "lo terçero, que de los pecados carnales non pregunte nin deçenda a las particulares çircunstanças; que a tales pecados commo estos, mientras mas espeçialmente deçendier a fablar dellos, tanto más la codiçia carnal se ençiende, por quanto son deletables, segund dize Aristotiles," postura procedente de Santo Tomás, en su Comentario de las Sentencias, libr. 4, d. 19. Actitud que triunfará, sobre todo, en el Concilio de Trento, al prohibir la exposición de modelos negativos sobre la sexualidad, puesto que podría despertar el deseo e incitar a un pecado desconocido, como intuía también el obispo Gonzalo de Alba: "E de las espeçias deste pecado [se trata del pecado contra natura] non queremos escrevir, e aconsejamos que non se revelen, mas que preguntele muy cautelosamente, en manera que si el pecador las non sabe, que las non deprenda (...)," y de ahí la desaparición del pecado sodomítico y otros contra natura de la comedia hispánica.

Tanto el obispo Gonzalo de Alba como un siglo después Luis Vives tuvieron actitudes aparentemente contradictorias; el primero de ellos ve la necesidad de preguntar exaustivamente en la confesión los motivos, causas y circunstancias del pecado para cuantificar la pena, pero al mismo tiempo reconoce que el descender a detalles demasiado concretos puede ser fuente asimismo de incitación a nuevas maneras desconocidas de pecar; para el humanista valenciano, la primitiva comedia (en concreto la Celestina) es una reprobación amorosa y por

${ }^{18}$ Ferrer, "El erotismo," p. 66 (véase nota 7). 
tanto se acepta su moralidad, pero también ve los peligros que puede ocasionar al lector/espectador no advertido la incitación e imitación de sus protagonistas. Esta postura ambivalente de la Iglesia y de los moralistas continuó fluctuante hasta el Concilio de Trento, donde se tomó partido por la segunda de las posturas.

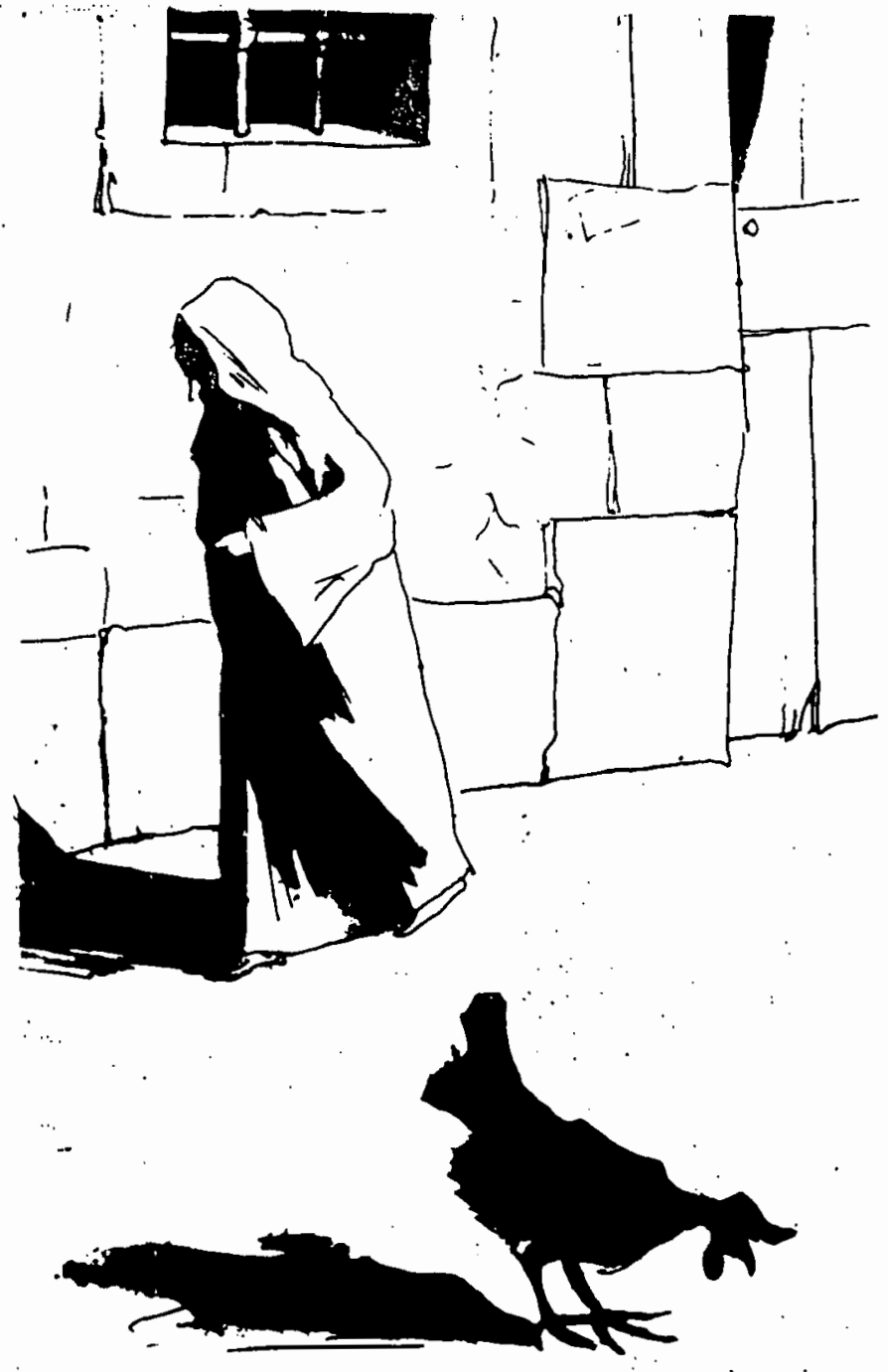

Celestina scuttling along the street. Illustration by Dodie Masterman. London: Folio Society, 1973 

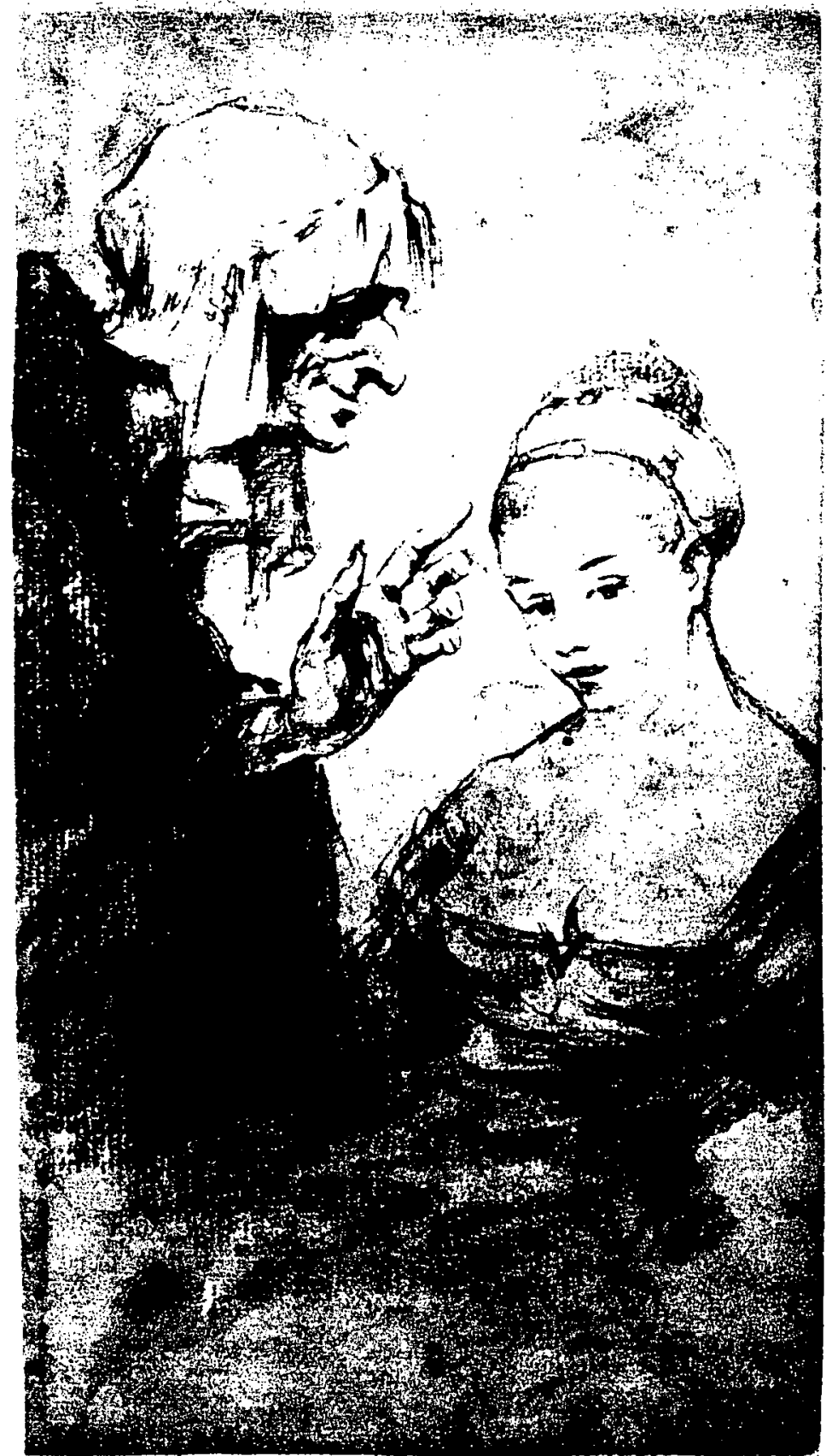

Cover art by Chico Prats. Barcelona: Maucci, 1961. 